\title{
Wielokulturowość we współczesnych polskich badaniach geograficznych i edukacji geograficznej - zarys problematyki
}

\author{
Multiculturalism in contemporary geographical studies \\ and geographical education in Poland - an outline of the subject
}

\author{
MAREK BARWIŃSKI \\ Wydział Nauk Geograficznych, Uniwersytet Łódzki \\ 90-142 Łódź, ul. Kopcińskiego 31, marek.barwinski@geo.uni.lodz.pl
}

\begin{abstract}
Zarys treści. Problematyka szeroko pojętej wielokulturowości jest w dyskursie publicznym zdominowana przez socjologów, historyków, politologów, w mniejszym stopniu przez geografów. W artykule podjęto próbę omówienia badań geograficznych dotyczących wielokulturowości Polski oraz regionu Europy Środkowo-Wschodniej. Z powodu ich liczebności i różnorodności, ograniczono się do prac współczesnych naukowców, publikowanych po roku 1990, pomijając bogaty dorobek wcześniejszych pokoleń polskich geografów. Jednym z celów artykułu jest próba wyjaśnienia przyczyn i konsekwencji istotnych dysproporcji w zainteresowaniu różnymi aspektami wielokulturowości, wyraźnie widocznymi zarówno w pracach naukowych, jak i w procesie edukacji geograficznej. Współczesne dynamiczne przemiany geopolityczne, demograficzne i kulturowe, zarówno w skali Europy, jak i Polski, stawiają przed geografami nowe wyzwania badawcze dotyczące wielokulturowości, zwłaszcza dotyczące relacji pomiędzy poszczególnymi narodowościami, grupami regionalnymi oraz wyznaniowymi, także spoza europejskiego kręgu kulturowego, w zmieniających się realiach społecznych i politycznych. Dlatego celem artykułu jest także zwrócenie uwagi geografów na potrzebę intensyfikacji badań dotyczących zarówno tzw. mniejszości regionalnych, jak i społeczności wywodzących się ze środowisk imigranckich.
\end{abstract}

Słowa kluczowe: wielokulturowość, wieloetniczność, dziedzictwo kulturowe, regiony wielokulturowe, struktura narodowościowa, mniejszości, imigranci.

\section{Wprowadzenie}

Wielokulturowość - to najprościej współistnienie na danym obszarze społeczności o różnych kulturach oraz odmiennych systemach wartości: pochodzeniu, tradycjach, obyczajach, religiach, językach. Najczęściej jest ona spowodowana zróżnicowaniem narodowościowo-wyznaniowym danej populacji 
i w tradycyjnym rozumieniu pojęcie to jest niejednokrotnie stosowane jako synonim wieloetniczności.

Współcześnie wielokulturowość jest najczęściej konsekwencją migracji (dobrowolnych lub wymuszonych) oraz procesów integracji polityczno-gospodarczej, zwłaszcza szeroko pojętej globalizacji. W przeszłości - poza migracjami, różnego rodzaju akcjami osiedleńczymi oraz przekształceniami gospodarczymi - bardzo istotną przyczyną prowadzącą do powstania regionów oraz społeczeństw wielokulturowych, były zmiany granic, ekspansja terytorialna państw i kolonizacja (Koter, 1993, 2003; Kowalski, 1999, 2010).

Specyficzną formą współczesnej wielokulturowości jest także ekspansja tzw. „kultury Zachodu”, będąca konsekwencją procesów globalizacji - a raczej „westernizacji” - społeczeństw Azji, Afryki czy Ameryki Łacińskiej, wkomponowania europejsko-amerykańskich elementów (mediów, wzorców zachowań, rozrywki, ubioru, kuchni) w kultury regionalne i lokalne.

Wielokulturowość jest rozumiana także jako polityka władz, zwłaszcza w państwach zachodniej Europy, zmierzająca do niwelacji napięć społecznych związanych z faktem zróżnicowania kulturowego danej populacji, nastawiona na integrację imigrantów w społeczeństwie państwa osiedlenia.

Podstawowymi punktami odniesienia geograficznych badań dotyczących wielokulturowości jest przestrzeń, środowisko geograficzne oraz elementy społeczno-kulturowe, przy jednoczesnym uwzględnieniu wpływu uwarunkowań historycznych i politycznych. Silne związki wielokulturowości z państwem i zamieszkującymi go zróżnicowanymi zbiorowościami, dają możliwość badania jej z perspektywy geografii politycznej i geografii ludności (m.in. w ramach wzajemnych relacji grup większościowych z mniejszościowymi, zróżnicowania narodowościowego i wyznaniowego, przemian tożsamości, procesów migracji), a poprzez odniesienie wielokulturowości do dziedzictwa kulturowego (szczególnie materialnego) badań z zakresu geografii historycznej i geografii kultury. Zajmując się problematyką wielokulturowości, geografia korzysta z dorobku innych dyscyplin, przede wszystkim historii, ale także socjologii, etnologii, politologii i statystyki (Rykała, red., 2013).

\section{Wielokulturowość w geografii}

Geograficzne badania dotyczące wielokulturowości najczęściej koncentrują się na trzech, niejednokrotnie zazębiających się, aspektach:

- zróżnicowanie narodowościowe i religijne,

- regiony wielokulturowe, zwłaszcza pogranicza,

- dziedzictwo kulturowe. 


\section{Wielokulturowość jako konsekwencja zróżnicowania narodowościowego i religijnego}

Geografowie badają mniejszości narodowe (etniczne) i religijne (wyznaniowe) głównie $\mathrm{w}$ aspekcie przestrzennym, demograficznym, regionalnym oraz instytucjonalno-organizacyjnym. W Polsce, z powodu zmiennych i specyficznych uwarunkowań politycznych w XX w., podjęto także próby geograficzno-politycznej analizy wpływu zmian ustrojowych na przekształcenia struktury narodowościowej i wyznaniowej, szczególnie pod względem terytorialno-liczebnym oraz polityczno-organizacyjnym, zarówno w odniesieniu do ogółu narodowości i grup wyznaniowych, jak i poszczególnych mniejszości (m.in.: Sobczyński, 2000; Gawryszewski, 2005; Eberhardt, 2006, 2008a, 2010; Rykała, 2007, 2011; Barwiński, 2013). Dzięki temu, że geografia polityczna i historyczna łączy m.in. badania dotyczące problematyki granic, pograniczy oraz mniejszości narodowych i religijnych, liczne są prace geograficzne dotyczące analiz struktury etnicznej i wyznaniowej na współczesnych polskich pograniczach (m.in.: Eberhardt, 1997a; Kowalski, 1998, 1999; Heffner, 1998; Barwiński, 1999, 2004; Soja, 2001; Szczepankiewicz-Battek, 2001, 2005a; Heffner i Solga, 2003).

Coraz częstsze są prace komparatystyczne, w których porównuje się sytuację mniejszości narodowych w Polsce z sytuacją narodowościową w innych państwach, zwłaszcza wschodnich sąsiadów Polski. Jest to spowodowane obecnością m.in. licznych skupisk autochtonicznej ludności polskiej zamieszkującej dawne wschodnie regiony Rzeczpospolitej, istotnymi różnicami sytuacji polityczno-prawnej mniejszości narodowych w poszczególnych państwach Europy Środkowo-Wschodniej oraz rosnącym znaczeniem, niejednokrotnie konfliktogennym, tych społeczności w relacjach międzypaństwowych. W pracach geograficznych szczególną uwagę zwraca się na porównanie potencjału demograficznego oraz rozmieszczenia i stopnia koncentracji przestrzennej mniejszości w poszczególnych państwach, a także przyczyny i konsekwencje wyraźnej asymetrii ilościowej oraz prawno-instytucjonalnej sytuacji mniejszości narodowych w Polsce oraz na terytoriach jej wschodnich sąsiadów (m.in. Eberhardt, 1994 a, b, 1996, 1998b; Kowalski, 1999, 2002, 2013b; Barwiński, 2012; Barwiński i Leśniewska, 2014; Leśniewska, 2014).

Czynnikiem niejednokrotnie istotniej różnicującym niż odmienność narodowościowa i silniej wpływającym na wielokulturowość danej zbiorowości jest jej zróżnicowanie wyznaniowe. Przynależność religijna poszczególnych społeczności ma bezpośredni wpływ na ich odmienność kulturową i społeczną, a niekiedy także polityczną czy gospodarczą. Bardzo wyraźnie jest to widoczne na ziemiach polskich, zarówno z uwagi na wielowiekową obecność różnorodnych grup wyznaniowych, jak i fakt dominacji do XIX w. tożsamości religijnej nad narodową wśród dużej części społeczeństwa. Badania geograficzne, dotyczące głównie przestrzennego aspektu zróżnicowania wyznaniowego, wzajemnych relacji 
zachodzących pomiędzy społecznościami kierującymi się określonymi zasadami wiary a środowiskiem ich życia, roli grup religijnych w organizacji przestrzeni miejskiej, funkcjonowania mniejszości wyznaniowych, religijnego dziedzictwa kulturowego, ruchu pielgrzymkowego i turystyki religijnej, są wśród polskich geografów licznie reprezentowane (m.in.: Jackowski, 1991, 2003; Jackowski i inni, 1995; Dzieciuchowicz i inni, 2004; Szczepankiewicz-Battek, 2005b; Klima, 2011; Rykała, 2011; Bilska-Wodecka, 2012; Sołjan, 2012; Tanaś, 2013).

Zdecydowanie najczęściej podmiotem badań geograficznych są tzw. mniejszości tradycyjne, historyczne, od wieków zamieszkujące w ramach państwa polskiego, będące swoistym reliktem wielonarodowej i wielowyznaniowej Rzeczypospolitej (Żydzi, Niemcy, Ukraińcy, Białorusini, Litwini, Ormianie, Rosjanie, Czesi, Słowacy, Łemkowie, Tatarzy, Romowie, Karaimi). Mniejszości te, w wyniku II wojny światowej oraz polityki władz komunistycznych uległy istotnym przekształceniom terytorialnym, ilościowym, instytucjonalnym, społecznym i kulturowym. Niejednokrotnie zamieszkiwane przez nie regiony zostały podzielone granicami państwowymi, a ludność objęta akcjami przesiedleńczymi o różnej skali, natomiast poczucie odrębności narodowej było osłabiane asymilacyjną polityką władz, prowadzoną $\mathrm{w}$ ramach budowania społeczeństwa monoetnicznego. Wszystkie te elementy przyczyniają się do naturalnego skupienia dociekliwości naukowej na tych narodowościach (m.in.: Eberhardt, 1996, 2006, 2008a; Kowalski, 1998, 1999; Sobczyński, 2000; Gawryszewski, 2005; Barwiński, 2013).

Rzadziej podmiotem badań geograficznych są tzw. mniejszości regionalne, a raczej etniczno-regionalne, określane także mianem „mniejszości postulowanych". Często są one postrzegane (oraz badane i opisywane) w kategoriach nie etnicznych, lecz wyłącznie etnograficzno-kulturowych, co współcześnie jest anachronizmem. Od początku XXI w. mamy do czynienia w Polsce z silnym wzrostem aspiracji politycznych i narodowych - skorelowanym z dynamicznym wzrostem liczebności i różnorodności - grup regionalnych, co pokazują m.in. wyniki spisów powszechnych z 2002 oraz 2011 r. Ślązacy i Kaszubi, mimo że wielokrotnie liczniejsi od wszystkich tzw. mniejszości tradycyjnych oraz aktywniejsi pod względem organizacyjnym, społecznym i politycznym od większości spośród nich, nadal zdecydowanie rzadziej są obiektem zainteresowania naukowców zajmujących się problematyką narodowościową (Janicki, 2009). Wydaje się, że jedną z głównych przyczyn jest utrzymująca się niechęć do ich postrzegania i definiowania także $\mathrm{w}$ kategoriach etnicznych, a tym samym włączania w nurt badań dotyczących struktury narodowościowej Polski. Intensyfikacja badań grup etniczno-regionalnych (zwłaszcza Ślązaków i Kaszubów), dotycząca ich rzeczywistych aspiracji narodowych i politycznych (a nie tylko aspiracji niektórych liderów), genezy i przejawów autoidentyfikacji, stosunku do państwa polskiego, a także potencjalnego zagrożenia ruchami o charakterze separatystycznym i izolacjonistycznym, jest dużym wyzwaniem dla geografów zajmujących się problematyką współczesnego zróżnicowania narodowościowego Polski. 
W marginalnym stopniu prowadzi się badania nad tzw. nowymi mniejszościami, czyli coraz liczniejszymi grupami, będącymi rezultatem migracji ekonomicznych (rzadziej politycznych) z państw postradzieckich oraz azjatyckich i afrykańskich (głównie Wietnamczyków, Czeczenów, Arabów, Hindusów, Chińczyków). Rozwinięcie tego typu badań jest bardzo istotne, przede wszystkim dlatego, że społeczności te, w odróżnieniu od mniejszości tradycyjnych oraz regionalnych, z reguły są całkowicie odmienne kulturowo i społecznie, izolowane i najczęściej niezintegrowane z większością społeczeństwa, co często przyczynia się do powstawania konfliktów i utrwalania negatywnych stereotypów, a ich rzeczywista lub potencjalna obecność w polskim społeczeństwie wywołuje coraz większe emocje.

W geograficznych badaniach dotyczących struktury narodowościowej, badania empiryczne zdecydowanie dominują nad teoretycznymi. Z nielicznych geograficznych opracowań teoretycznych, na szczególną uwagę zasługują propozycje typologii mniejszości narodowych i ludności pogranicza (m.in. Koter, 1993, 1995) oraz koncepcje metodologii badań mniejszości narodowych i religijnych w specyfice polskich uwarunkowań badawczych (m.in. Sobczyński, 2012; Sobczyński i Grabowska, 1993).

\section{Regiony wielokulturowe}

Regiony wielokulturowe, to z reguły obszary graniczne położone na skraju dwóch lub więcej ekumen narodowych. Zamieszkuje je mieszanka ludności autochtonicznej i napływowej o różnym pochodzeniu (osadnicy, kolonizatorzy, uciekinierzy, przesiedleńcy), niekiedy z odległych krajów, choć najczęściej z państw sąsiednich. Ludność napływowa z reguły jest tu obecna od wielu pokoleń, bardzo rzadko są to nowi imigranci. Regiony te są wewnętrznie zróżnicowane. Mogą składać się z przedstawicieli kilku narodów, grup etnicznych lub kulturowych o różnym pochodzeniu, poziomie rozwoju społecznego i gospodarczego, a także statusie politycznym. Grupy te moga zajmować własne niewielkie terytoria lub żyć $\mathrm{w}$ rozproszeniu. Ich wzajemne kontakty mogą mieć charakter pokojowego współżycia lub wrogich konfliktów. Wszystkie regiony wielokulturowe mają charakter dynamiczny. Ich struktura etniczna i specyfika kulturowa zmienia się zależnie od wielu czynników i procesów demograficznych, społecznych, ekonomicznych czy politycznych (Koter, 2003).

Oczywiste jest, że zarówno ukształtowane historycznie regiony wzajemnego „wymieszania się" kilku sąsiadujących narodów lub grup etnicznych, jak i obszary masowej współczesnej imigracji ekonomicznej i politycznej, muszą w efekcie stać się wielokulturowe. Jednak jest pomiędzy nimi bardzo wyraźna różnica, którą można określić jako różnicę między „wielokulturowością autochtonów” a „wielokulturowością gości”. 
Specyficznym typem wielokulturowości - którą należy inaczej badać oraz inaczej o niej nauczać - są regiony, gdzie w konsekwencji różnych, często wielowiekowych procesów historycznych (akcji osiedleńczych, migracji, zmian granic, ekspansji politycznej i gospodarczej poszczególnych państw), kształtowało się społeczeństwo wielokulturowe. Ludność napływowa tak długo i wyraźnie kreowała krajobraz kulturowy, etniczno-wyznaniowy, gospodarczy, polityczny tych regionów, tak mocno „wrosła” w jego historię, geografię i gospodarkę, że możemy mówić o „wielokulturowości autochtonów”, gdzie wszystkie narodowości, zarówno lokalne, jak i napływowe, są współcześnie „u siebie”.

Oczywiście w takich regionach zróżnicowanie społeczne, kulturowe czy ekonomiczne, pomiędzy ludnością napływową i miejscową było początkowo wyraźne. Różnice społeczne były pogłębiane poprzez charakter osadnictwa, ponieważ ludność autochtoniczna (głównie wiejska), różniła się zdecydowanie od napływowej (z reguły miejskiej), pod względem zawodowym, ekonomicznym i poziomu wykształcenia. Współżycie społeczne w tego typu regionach rzadko miało charakter partnerski. Z reguły grupa dominująca - szczególnie pod względem ekonomiczno-kulturowym, nie zawsze liczebnym - narzucała swoją kulturę narodom autochtonicznym, np. Niemcy na Śląsku, Pomorzu i Mazurach, Polacy na kresach wschodnich, Włosi i Turcy na Bałkanach, Węgrzy na Słowacji i w Rumunii, Rosjanie w byłych republikach ZSRR (Koter, 1995, 1997, 2003, Eberhardt, 1996, 2002, 2008b; Babiński, 1997; Kowalski, 2013a). Jednocześnie miała ona ogromny wpływ na rozwój społeczny i gospodarczy tych obszarów, a z biegiem czasu doszło do daleko posuniętej integracji społeczno-kulturowej, zarówno pomiędzy poszczególnymi narodowościami, jak i z państwem zamieszkania. Na to nakładało się osadnictwo narodów przez wieki żyjących w diasporze, a mających ogromny wpływ na kreowanie życia społecznego, gospodarczego i kulturalnego regionów zamieszkania - głównie Żydów i Ormian. Tego typu regiony wielokulturowe są współcześnie powszechne w Europie Środkowo-Wschodniej, m.in. na Bałkanach, w Polsce, Rumunii, Słowacji, na Ukrainie, Białorusi, Litwie, Łotwie.

Z zupełnie innym typem wielokulturowości mamy do czynienia w regionach koncentracji imigrantów ekonomicznych, typowych dla współczesnych krajów wysoko rozwiniętych, zwłaszcza Ameryki Północnej i Europy Zachodniej. Te grupy są przestrzennie silnie zatomizowane, często ograniczone do „dzielnic etnicznych” w wielkich miastach. Reprezentują „wielokulturowość gości”, ponieważ ludność napływowa, pochodząca z reguły z zupełnie odmiennych kręgów kulturowych, często nawet po upływie kilku pokoleń zachowuje daleko posuniętą odrębność oraz niechęć do integracji w państwie osiedlenia. Także w bardzo ograniczonym zakresie angażuje się w życie społeczne i polityczne danego kraju. Społeczności te, zarówno przez samych siebie, jak i przez „autochtonów” są odbierane i traktowane jako „zewnętrzni goście”. 
Tego typu regiony wielokulturowe zdecydowanie rzadziej są przedmiotem badań geograficznych; wyjątkami są pierwsze prace dotyczące polskich imigrantów w Wielkiej Brytanii i Irlandii (m.in.: Grabowska-Lusińska i Okólski, 2008; Matkowski i Dominik, 2010; Kubal, 2012), a wcześniej nieliczne opracowania dotyczące współczesnej sytuacji Polonii w Stanach Zjednoczonych i Meksyku. Natomiast obszary wielokulturowe kształtowane przez mniejszości narodowe w Polsce (m.in.: Podlasie, Śląsk, Warmia i Mazury, Małopolska, Podkarpacie) czy przez ludność polską na Litwie, Łotwie, Białorusi, Ukrainie, są pod względem społeczno-geograficznym wszechstronnie badane i opisywane.

Szczególnym przykładem regionu wielokulturowego popularnego w badaniach geograficznych, jest pogranicze - rozumiane jako strefa, obszar przejściowy pomiędzy dwoma lub kilkoma państwami, względnie narodami. Pojawia się najczęściej w konsekwencji wielokrotnych historycznych zmian przynależności politycznej danego terytorium, wymieszania się ludności w wyniku procesów osadniczych i krzyżowania się wpływów politycznych. W badaniach geograficznych takie regiony są najczęściej rozpatrywane w aspekcie przestrzennym oraz społeczno-kulturowym.

Pogranicze zazwyczaj (choć niekoniecznie) obejmuje obszar położony po obu stronach granicy państwowej, jest nią rozdzielone. Od charakteru tej granicy, jej funkcji, zależy jakość i intensywność przenikania elementów kultury. Gdy granica jest barierą, pogranicza po obu jej stronach różnicują się, ulegają kulturze własnych centrów. Jeśli granica jest lub staje się przepuszczalna, otwarta, obszary pogranicza upodabniają się, ulegają kulturowemu i społecznemu wymieszaniu.

Jednak nie każde pogranicze musi być bezpośrednio związane z przebiegiem granicy państwowej. Można wyróżnić, pod względem kontaktu społeczno-kulturowego, pogranicza wewnętrzne i zewnętrzne. Pierwsze z nich występują w obrębie danego państwa, pomiędzy przedstawicielami dwóch lub więcej narodów. Najczęściej są to tereny zamieszkiwania mniejszości narodowych lub etnicznych oraz ich kontaktów z większością. Typowym obszarem pograniczy wewnętrznych jest Polska wschodnia i północno-wschodnia. Pogranicza zewnętrzne występują na terenach nadgranicznych sąsiadujących państw. Kształtują się one w konsekwencji otwarcia granic i kontaktów pomiędzy przedstawicielami sąsiednich narodów. Mają bardzo różną formę - od kontaktów rodzinnych, poprzez międzyetniczne, aż po formy instytucjonalne, takie jak np. euroregiony (Barwiński, 2002).

$\mathrm{Na}$ obszarze pogranicza, w konsekwencji stykania i mieszania się rozmaitych społeczeństw, o odmiennych tradycjach kulturowych oraz różnych systemach wartości, dochodzi do powstania „kultury pogranicza”, o specyficznych cechach, licznych zapożyczeniach, bardzo różnorodnej. W warunkach długotrwałego przenikania kultur formułuje się również nowy typ człowieka, określany czasami jako „człowiek pogranicza”, kształtowany przez co najmniej dwie kultury, a nawet podzielający życie kulturalne, tradycje i wartości dwóch lub czasami kilku społeczności. Stosunkowo częstym zjawiskiem jest poczucie przynależno- 
ści równocześnie do dwóch narodów lub zmiany własnej przynależności narodowej oraz występowanie zjawiska dwu- lub wielojęzyczności (Sadowski, 1995). Kształtują się również nowe formy społecznej tożsamości, nowe „całości kulturowe”, powstają społeczności pogranicza wraz z ich odrębną kulturą, np.: Ślązacy, Mazurzy, Warmiacy, Poleszucy. Na pograniczach, zwłaszcza pomiędzy ludnością pokrewną kulturowo, dominuje poczucie tożsamości regionalnej, autochtonicznej, powstaje kategoria ludności, która, bez względu na obiektywną przynależność narodową, określa się jako „tutejsi”. Zjawisko takie występuje również współcześnie na obszarze Polski, wśród części mieszkańców Podlasia, Warmii, Mazur, Kaszub, Śląska.

Pojęcie pogranicza najczęściej rozpatrywane jest w ujęciu geograficzno-historycznym, ale można je rozszerzyć także na sferę kulturowo-symboliczną (Babiński, 1994). Często przestrzeń współczesnego kontaktu grup narodowościowych nie jest związana z historycznymi obszarami zamieszkiwania tych społeczności. Niejednokrotnie granice i pogranicza są wyznaczane symbolicznie, głównie na podstawie zróżnicowania kulturowego. Tego typu pogranicza występują wspó1cześnie głównie w wieloetnicznych miastach, w których różne narodowości tworząc własne dzielnice, swojego rodzaju getta, wytwarzają współcześnie granice, jak i pogranicza kulturowo-etniczne. Podobna sytuacja pogranicza, gdzie nie występuje historyczna łączność z zamieszkiwanym obszarem ale mamy do czynienia z podobną problematyką jak na „typowych” pograniczach, istnieje m.in. na pograniczach pomiędzy Polakami a przesiedloną na tereny północnej i zachodniej Polski ludnością ukraińską i łemkowską, lub też pomiędzy ludnością rodzimą a wszelkiego typu imigrantami (np. ludność turecka w Niemczech, arabska we Francji, hinduska, pakistańska, polska w Wielkiej Brytanii).

\section{Dziedzictwo kulturowe}

W Polsce - oraz w wielu innych państwach -liczne są przypadki przerwania ciągłości wielokulturowości danego regionu. Jednak zawsze (lub prawie zawsze) pozostają materialne ślady przeszłości. Niejednokrotnie są one ważnym elementem historii, tożsamości, identyfikacji miasta, regionu, państwa. Dlatego przy badaniu wielokulturowości należy uwzględnić także to, co otrzymaliśmy w spad$\mathrm{ku}$ - wielokulturowe dziedzictwo (Rykała, red., 2013). Zwłaszcza, że niekiedy jedynym świadectwem występowania na danym obszarze np. mniejszościowych grup narodowościowych, etnicznych, językowych lub wyznaniowych, często mających wielowiekową tradycję współkształtowania danego regionu lub miasta, są współcześnie tylko relikty ich materialnej kultury. Najczęściej są to zabytki architektury - zamki, pałace, kamienice, świątynie, cmentarze, fabryki.

Z uwagi na specyfikę polskiej historii, do regionów, w których koncentrują się geograficzne badania dziedzictwa kulturowego należą przede wszystkim Śląsk i Pomorze z reliktami kultury niemieckiej, Polska południowo-wschodnia 
z bogatym dziedzictwem żydowskim, ukraińskim i łemkowskim oraz Podlasie z wyraźnymi śladami bytności białoruskiej, tatarskiej, żydowskiej, litewskiej i rosyjskiej. Wśród prac geograficznych istotne miejsce zajmują także opracowania dotyczące roli mniejszości narodowych w organizacji przestrzeni miejskiej oraz związanego z ich obecnością dziedzictwa kulturowego, szczególnie liczne w łódzkim ośrodku geograficznym, z uwagi na specyficzny przebieg rozwoju tzw. „Łodzi przemysłowej” określanej jako „miasto czterech kultur” - polskiej, żydowskiej, niemieckiej i rosyjskiej, co do dzisiaj jest widoczne w jej krajobrazie kulturowym (m.in.: Liszewski, 1991; Koter i inni, red., 2005; Kulesza i inni, red., 2010; Kulesza, 2013). Tego typu badania geograficzno-historyczne dotyczą także reliktów wielowiekowej polskiej obecności na dawnych wschodnich ziemiach Rzeczypospolitej, szczególnie w granicach współczesnej Litwy, ale także Ukrainy, Białorusi i Łotwy (m.in.: Eberhardt, 1998; Figlus, 2009, 2015; Rykała, 2009; Kowalski, 2010, 2013 a, b; Leśniewska i Barwiński, 2015).

Problematyką łączącą dwa, wspomniane powyżej, geograficzne aspekty wielokulturowości - region wielokulturowy i dziedzictwo kulturowe - jest szeroko rozumiane pojęcie krajobrazu kulturowego, wszechstronnie omawiane w polskiej literaturze naukowej (m.in.: Myga-Piątek, red., 2001, 2004, 2005; Orłowska, red., 2002, 2004; Rembowska, 2002, 2007; Rykała, 2003, 2013; Plit F., 2005, 2008, 2010, 2011, 2013, 2014; Czepczyński, 2006, 2008, 2010; Kulesza i Rykała, 2006; Plit J., red., 2006, 2011, 2015; Jackowski, 2007; Kozłowski, 2011; Awramiuk-Godun, 2013; Kulesza, 2014; Awramiuk-Godun i Iwańczak, 2015). Liczne, cenne poznawczo artykuły dotyczące zarówno rozważań teoretycznych, jak i badań empirycznych oraz ewolucji krajobrazu kulturowego, metod badań i studiów przypadku, są systematycznie publikowane m.in. w czasopiśmie Prace Komisji Krajobrazu Kulturowego pod redakcją Urszuli Myga-Piątek oraz Joanny Plit. Tematyce tej poświęcono także publikowaną w latach 2002-2008 serię wydawniczą Kulturowy aspekt badań geograficznych. Studia teoretyczne i regionalne pod redakcją Elżbiety Orłowskiej.

\section{Wielokulturowość w akademickiej edukacji geograficznej}

Na Uniwersytecie Warszawskim oraz Jagiellońskim podjęto badania dotyczące zróżnicowanych etnicznie i kulturowo regionów pogranicza w dydaktyce geografii i edukacji regionalnej, a także szkolnictwa mniejszości narodowych w Polsce. Aktualne badania geograficzne dotyczące wielokulturowości w edukacji koncentrują się głównie na edukacji międzykulturowej na pograniczach (m.in.: Awramiuk-Godun, 2008, 2009, 2010, 2011), znaczeniu edukacji międzykulturowej w kontekście integracji Polski z państwami Unii Europejskiej (m.in.: Piróg, 2007, 2008 a, b), a także nauczania o mniejszościach narodowych i szkolnic-

twa dla mniejszości etnicznych, zwłaszcza Romów (m.in.: Osuch, 2007; Świętek i inni, 2014). Ponadto w geograficznych ośrodkach akademickich zlokalizowa- 
nych w regionach wielokulturowych (m.in. Kraków, Katowice, Lublin, Gdańsk, Wrocław) lub prowadzących szeroko zakrojone badania z zakresu geografii politycznej, geografii kultury i geografii religii (m.in. Łódź, Warszawa, Kraków, Gdańsk) powszechne są wykłady, konwersatoria i ćwiczenia terenowe dla studentów, dotyczące różnych aspektów wielokulturowości (m.in. zróżnicowania narodowościowego i wyznaniowego, dziedzictwa kulturowego), zarówno w ujęciu regionalnym, jak i globalnym.

Istotnym wkładem geograficznego środowiska akademickiego w upowszechnianie wśród uczniów gimnazjów i liceów wiedzy o własnym regionie, w tym o jego specyfice kulturowej, było włączenie się naukowców w przygotowanie i opracowanie „podręczników wiedzy o regionie”. Ich pojawienie się na początku XXI w., zostało spowodowane dwoma głównymi czynnikami - wprowadzeniem w 1999 r. reformy administracyjnej, która dzieliła Polskę na 16 dużych województw oraz ówczesną reformą szkolnictwa, która w nowym programie nauczania kładła nacisk na nauczanie zintegrowane, m.in. nauczanie regionalne. Podręczniki „wiedzy o regionie” w swoim założeniu miały dotyczyć poszczególnych nowych województw traktowanych jako regiony geograficzno-historyczne i przekazywać uczniom całą interdyscyplinarną wiedzę o regionie zamieszkania. Obok szeregu informacji dotyczących specyfiki geograficznej, gospodarczej i ludnościowej, podręczniki zawierają także wiadomości dotyczące dziedzictwa kulturowego oraz historycznie ukształtowanej wielokulturowości danego województwa, jej przyczyn, uwarunkowań i konsekwencji (m.in.: Koter i inni, 2000, 2002; Bartoszewska, 2002; Okła, red., 2002; Kuźnieców, 2003; Nowak, red., 2003).

Niestety obecnie podręczniki tego typu nie mogą spełniać swojego zadania edukacyjnego. Według kolejnej, wprowadzonej w 2008 r. podstawy programowej, w ramach nauczania geografii nie ma miejsca na osobne zajęcia dotyczące regionu, a treści związane z tematyką regionalną zeszły na dalszy plan. Teoretycznie uczniowie mogą zdobywać informacje o własnym regionie na lekcjach wiedzy o kulturze, historii czy wiedzy o społeczeństwie, jednak zależy to głównie od zaangażowania i inicjatywy nauczyciela.

\section{Wielokulturowość w szkolnych podręcznikach geograficznych}

We współczesnej geograficznej edukacji szkolnej, realizowanej według nowej podstawy programowej, nauczanie o wielokulturowości skupia się na jej trzech aspektach $^{1}$ :

- zróżnicowanie kulturowe ludności świata,

- wielokulturowe skupiska imigrantów w krajach wysokorozwiniętych,

- historycznie ukształtowana wielokulturowość Polski.

1 Na podstawie podręczników do geografii dla szkół gimnazjalnych oraz ponadgimnazjalnych (licea i technika), wydawnictw Nowa Era, PWN, WSiP, Operon. Te oficyny wydają obecnie ponad 90\% podręczników do geografii we wszystkich typach szkół. 
W podręcznikach gimnazjalnych problematyka wielokulturowości pojawia się po raz pierwszy w programie klasy II, gdzie omawiana jest geografia świata w ujęciu regionalnym. Jest ona sygnalizowana w rozdziałach dotyczących ludności poszczególnych kontynentów. Kwestie zróżnicowania rasowego, etnicznego, językowego i kulturowego są jednak traktowane lakonicznie i zdecydowanie ustępują problematyce stricte demograficznej i urbanizacyjnej (Majchrzak, 2009; Szczypiński i Wójtowicz, 2010). Tylko sporadycznie, w przypadku regionu szczególnie, według autora, istotnego pod względem zróżnicowania mieszkańców (Ameryka, Europa) jest on omawiany w aspekcie kulturowym nieco obszerniej (Majchrzak, 2009).

W nauczaniu gimnazjalnym, w ramach geografii Polski, także w bloku tematycznym dotyczącym ludności i urbanizacji, pojawiają się zagadnienia struktury narodowościowo-etnicznej, gdzie na zaledwie 2-3 stronach autorzy przekazują uczniom podstawowe informacje o liczebności i rozmieszczeniu tzw. tradycyjnych mniejszości, jednocześnie podkreślając, że „obecnie Polska jest krajem niemal jednolitym narodowościowo" (Szubert, 2010). Tylko nieliczne wydawnictwa traktują te tematykę nieco szerzej, wprowadzając także podstawowe informacje dotyczące najliczniejszych grup regionalnych (Ślązacy, Kaszubi) i struktury wyznaniowej, czy porównując wyniki spisów ludności z okresu międzywojennego oraz początku XXI w. (Majchrzak i Wład, 2010). Niestety, w niektórych podręcznikach dla uczniów gimnazjów, traktujących o geografii Polski, nie ma wyodrębnionych żadnych rozdziałów dotyczących zróżnicowania narodowościowego, wyznaniowego czy kulturowego (Chrabelski i Dudaczyk, 2010).

W edukacji ponadgimnazjalnej tematyka wielokulturowości także pojawia się w rozdziałach dotyczących geografii ludności, a szczególnie jej globalnego zróżnicowania rasowego, etnicznego, językowego, religijnego. Jest ona z reguły bogato ilustrowana przykładami z egzotycznych państw Azji, Afryki i Ameryki Łacińskiej. Omawiana jest zdecydowanie szerzej niż we wcześniejszym etapie edukacji. Dużo miejsca poświęca się przyczynom oraz konsekwencjom (zarówno pozytywnym, jak i negatywnym) szeroko pojętego zróżnicowania kulturowego oraz przenikania kultur, podkreślając znaczenie tolerancji i szacunku dla innych obyczajów i wierzeń. Za czynnik najmocniej wpływający na wielokulturowość uważa się zróżnicowanie wyznaniowe, kładąc nacisk na wpływ poszczególnych religii na życie społeczne i gospodarcze oraz różnice cywilizacyjne (Plit i inni, 2003; Łęcka i Mularczyk, 2012; Kop i inni, 2013; Rachwał, 2013). W aspekcie geograficznym, przestrzennym, wielokulturowość świata jest najczęściej ukazana i omawiana na przykładzie „kręgów kulturowych” (cywilizacyjnych) wyodrębnionych m.in. przez A. Toynbee, F. Konecznego czy S. Huntingtona (Plit i inni, 2003; Kurek, 2012; Zaniewicz, 2012; Kop i inni, 2013; Rachwał, 2013; Lenartowicz i Wójcik, 2014). Niestety, poza nielicznymi wyjątkami (Plit i inni, 2003), jest to przedstawiane skrótowo, bez krytycznej analizy takiego zgeneralizowanego i kontrowersyjnego „podziału świata”. 
Problematyka wielokulturowych skupisk imigrantów w krajach wysoko rozwiniętych (Ameryka Północna, Europa Zachodnia, niektóre kraje Zatoki Perskiej) pojawia się $\mathrm{w}$ podręcznikach przy omawianiu współczesnych migracji, jako jeden z jej istotnych aspektów. Obszernie są przedstawione czynniki intensyfikujące migrację oraz jej pozytywne i negatywne konsekwencje, zarówno dla krajów imigracyjnych, jak i emigracyjnych (Kurek, 2012; Zaniewicz, 2012; Kop i inni, 2013; Rachwał, 2013).

Wielokulturowość w odniesieniu do Polski jest rozpatrywana wyłącznie poprzez omówienie współcześnie niewielkiego zróżnicowania narodowo-etnicznego i wyznaniowego. Autorzy podręczników przypominają historyczne uwarunkowania przekształcenia Polski z kraju wielonarodowego w monoetniczny, podają liczebność i rozmieszczenie tzw. tradycyjnych mniejszości zamieszkujących współcześnie Polskę, wspominają także o grupach regionalnych (zwłaszcza Kaszubach i Ślązakach), przytaczają główne cechy etniczno-terytorialne obecnej struktury wyznaniowej, zwracają uwagę na wielowiekową obecność tych mniejszościowych społeczności na ziemiach polskich (Plit i inni, 2003; Więckowski i Malarz, 2014).

Z kolei w dziale „ludność Polski”, migracje zewnętrzne, które bezpośrednio wpływają na intensyfikację wielokulturowości, są omawiane wyłącznie w kontekście emigracji Polaków do Stanów Zjednoczonych i zachodniej Europy, nasilonej zwłaszcza po akcesji do Unii Europejskiej, natomiast nie wspomina się o rzeczywistym oraz potencjalnym napływie imigrantów do Polski (Więckowski i Malarz, 2014).

Wyraźnie widoczne w większości szkolnych podręczników szablonowe podobieństwo w przedstawianiu problematyki wielokulturowości, w skali i świata, i Polski, jest m.in. konsekwencją nakazu stosowania się przez autorów do jednolitej, zatwierdzonej przez MEN, podstawy programowej.

Takie podejście do tematyki wielokulturowości, odsuwające ją zarówno w czasie (historia Polski), jak i w przestrzenni (regiony geograficzne odległe od Polski), utwierdza uczniów w przekonaniu, że zamieszkiwany przez nich kraj jest i pozostanie monokulturowy.

\section{Wnioski}

Jedną z konsekwencji nasilających się procesów gospodarczej globalizacji, politycznej integracji oraz międzykontynentalnych migracji jest upowszechnienie wielokulturowości. Poszczególne społeczeństwa są i będą coraz bardziej wielokulturowe.

Polska jest specyficznym przykładem państwa, które w swojej historii ma niezwykle bogate tradycje jednego z najbardziej wielokulturowych i jednocześnie tolerancyjnych oraz otwartych na „innych” państw europejskich, którego współczesność cechuje homogeniczność narodowo-religijna i niechęć dużej czę- 
ści społeczeństwa (a także ugrupowań politycznych) do imigrantów, zwłaszcza spoza europejskich kręgów kulturowych.

Ta specyfika widoczna jest także w przedstawionym powyżej krótkim i z pewnością niekompletnym zarysie współczesnych badań geograficznych dotyczących wielokulturowości oraz jej obecności w edukacji geograficznej. Na podstawie przeprowadzonej analizy można sformułować kilka ogólnych wniosków:

- zdecydowana większość poruszanej tematyki badawczej dotyczy reliktów dawnej polskiej wielokulturowości - niewielkich liczebnie i silnie zintegrowanych z polskim społeczeństwem mniejszości narodowych, etnicznych i wyznaniowych, dziedzictwa kulturowego świadczącego o bogatej i dumnej historii ziem polskich oraz ciągle żywej, dzięki skupiskom polskiej mniejszości, obecności kultury i tradycji polskiej na dawnych kresach wschodnich. Można ją określić jako „wielokulturowość sentymentalną” (wewnętrzną, historyczną, tradycyjną, autochtoniczną);

- tę samą zależność widać w szkolnej edukacji geograficznej, która wielokulturowość w Polsce pokazuje przez pryzmat istniejącego od stuleci, ale współcześnie niewielkiego, zróżnicowania narodowo-religijnego, migracje poprzez wyjazdy Polaków do pracy w Wielkiej Brytanii, a społeczeństwa o innym kolorze skóry i wyznające religie niechrześcijańskie umiejscawia w odległych, egzotycznych krajach;

- pomimo wykazanego w ostatnich spisach powszechnych dynamicznego wzrostu liczebnego tzw. mniejszości regionalnych (zwłaszcza Ślązaków i Kaszubów), które zdominowały współczesną strukturę etniczną Polski, a także intensyfikacji ich aspiracji społecznych, kulturowych i politycznych, nadal nie spotkało się to z proporcjonalnym wzrostem zainteresowania badawczego geografów;

- w badaniach geograficznych całkowicie marginalizowana jest problematyka „wielokulturowości imigrantów” (zewnętrznej, współczesnej, napływowej), która jest od dziesięcioleci - a zwłaszcza obecnie - ważną tematyką badawczą, publicystyczną i polityczno-gospodarczą na obszarze Unii Europejskiej;

Takie postrzeganie i badanie wielokulturowości w polskiej geografii jest w dużym stopniu zrozumiałe, z jednej strony ze względu na historyczne i kulturowe znaczenie tzw. tradycyjnych mniejszości, a z drugiej strony z powodu nieatrakcyjności naszego kraju jako państwa osiedlenia dla imigrantów ekonomicznych oraz uchodźców politycznych z Bliskiego Wschodu i północnej Afryki.

Zdecydowana większość zamieszkujących współczesną Polskę mniejszości narodowych, etnicznych i regionalnych jest częścią historycznego, kulturowego i politycznego dziedzictwa Rzeczypospolitej, jest świadectwem dawnej złożoności i różnorodności Polski, częścią jej historii, teraźniejszości i - należy mieć nadzieję, że także - przyszłości. Należą do mniejszości, które mimo że „inne”, odrębne pod względem tożsamości narodowej, językowej czy wyznaniowej, sa „u siebie”, z wszelkimi wynikającymi z tego prawami i obowiązkami. Mimo pewnych różnic, są one silnie zintegrowane ze społeczeństwem polskim, według 
integracji rozumianej ,jako branie udziału w życiu większości i współtworzeniu kultury większości bez porzucania własnych wzorów" (Budyta-Budzyńska, 2010). Nie są to grupy izolowane w rozumieniu geograficznym, politycznym, społecznym, kulturowym lub gospodarczym, wręcz przeciwnie - bliskie kulturowo i obyczajowo, niewymagające specjalnych działań integracyjnych ze strony władz czy organizacji pozarządowych. O powszechnych, zwłaszcza w socjologii, modelach integracji grup mniejszościowych można mówić m.in. wobec muzułmanów w zachodniej Europie, Romów w środkowej Europie, ewentualnie Wietnamczyków w Polsce, ale z pewnością nie wobec mieszkających w Polsce np. Niemców, Ukraińców, Białorusinów, Żydów, Litwinów, Ślązaków czy Kaszubów.

Mimo to Polska, choć z pewnością w stopniu dużo mniejszym niż zachodnia Europa, nie uniknie dalszej, postępującej wielokulturowości, gdyż żadna z mniejszości w całości nie wyemigruje, ani całkowicie się nie zasymiluje. Wcześniej czy później zwiększy się także napływ imigrantów spoza europejskich kręgów kulturowych. Fale legalnej czy nielegalnej imigracji nie ominą Polski. Merytoryczne i mentalne przygotowanie społeczeństwa polskiego na tę „wielokulturowość imigrantów", wolne zarówno od populizmu, jak i tzw. politycznej poprawności, jest dużym wyzwaniem - nie tylko dla geografów, lecz także dla socjologów, politologów i historyków. Szczególnie że zarówno w społeczeństwie, jak i wśród części polityków, dominuje obawa przed napływem do Polski muzułmańskich uchodźców i imigrantów ekonomicznych, pomimo że na razie, z powodu ich niechęci do osiedlania się w tej części Europy, jest to sytuacja hipotetyczna.

Dalsze prowadzenie społeczno-geograficznych badań wielokulturowości oraz szersze wprowadzanie jej do edukacji geograficznej jest niezbędne, z powodu zarówno kultywowania polskich tradycji różnorodności społecznej, jak i rosnącego znaczenia autochtonicznych grup regionalnych oraz napływu imigrantów wywodzących się z całkowicie odmiennych kultur, zwłaszcza zaś z uwagi na dynamiczne przekształcenia geopolityczne, demograficzne i cywilizacyjne coraz szybciej zmieniające Europę, a wraz z nią i Polskę.

\section{Piśmiennictwo / References}

Awramiuk-Godun A., 2008, Pogranicza kulturowe w nauczaniu geografii Polski, Prace i Studia Geograficzne, 39, Warszawa, s. 35-42.

Awramiuk-Godun A., 2009, Pogranicze kultur: percepcja „własnego regionu” przez uczniów a edukacja regionalna, Wydawnictwo Uniwersytetu Warszawskiego, Warszawa.

Awramiuk-Godun A., 2010, O potrzebie uwzględniania tematyki dotyczacej miast pogranicza w edukacji geograficznej, [w:] M. Mularczyk (red.), Miasto w edukacji geograficznej, Instytut Geografii UJK, Kielce, s. 82-94.

Awramiuk-Godun A., 2011, Zróżnicowanie kulturowe Polski a ksztatcenie geograficzne, [w:] A. Cudowska (red.), Kierunki rozwoju edukacji w zmieniajacej sie przestrzeni społecznej, Trans Humana, Białystok, s. 595-602. 
Awramiuk-Godun A., 2013, Rozmieszczenie obiektów sakralnych jako kryterium wyznaczania zasięgu krajobrazu kulturowego pogranicza, Prace Komisji Krajobrazu Kulturowego PTG, 19, s. 62-72.

Awramiuk-Godun A., Iwańczak B., 2015, Wizualizacja kartograficzna krajobrazu pogranicza kulturowego - źródta i metody, Prace Komisji Krajobrazu Kulturowego PTG, 27, s. 95-108.

Babiński G., 1994, Pogranicze etniczne, pogranicze kulturowe, peryferie. Szkic wstęny problematyki, [w:] A. Sadowski (red.), Pogranicze. Studia Społeczne, 4, s. 5-28.

Babiński G., 1997, Pogranicze polsko-ukrainskie, Nomos, Kraków.

Bartoszewska M., 2002, Lubelszczyzna. Regionalna ścieżka edukacyjna, Mac Edukacja, Kielce.

Barwiński M., 1999, Wspótczesna tożsamość etniczna i kulturowa Łemków na obszarze Łemkowszczyzny - uwarunkowania $i$ konsekwencje, Acta Universitatis Lodziensis, Folia Geographica Socio-Oeconomica, 2, s. 53-69.

Barwiński M., 2002, Pogranicze w ujęciu geograficzno-socjologicznym - zarys problematyki, Acta Universitatis Lodziensis, Folia Geographica Socio-Oeconomica, 4, s. 11-23.

Barwiński M., 2004, Podlasie jako pogranicze narodowościowo-wyznaniowe, Wydawnictwo Uniwersytetu Łódzkiego, Łódź.

Barwiński M., 2012, Stosunki międzypaństwowe Polski z Ukraina, Białorusia i Litwa po 1990 roku w kontekście sytuacji mniejszości narodowych, Studia z Geografii Politycznej i Historycznej, 1, s. 139-166.

Barwiński M., 2013, Geograficzno-polityczne uwarunkowania sytuacji Ukraińców, Łemków, Biatorusinów i Litwinów w Polsce po 1944 roku, Wydawnictwo Uniwersytetu Łódzkiego, Łódź.

Barwiński M., Leśniewska K., 2014, Sytuacja mniejszości narodowych w Polsce i na Litwiestudium porównawcze, Przegląd Geograficzny, 86, 4, s. 499-524.

Bilska-Wodecka E., 2012, Człowiek religijny $i$ zwiąki wyznaniowe w przestrzeni miasta w XX i na początku XXI wieku, IGiGP UJ, Kraków.

Budyta-Budzyńska M., 2010, Socjologia narodu i konfliktów etnicznych, Wydawnictwo Naukowe PWN, Warszawa.

Chrabelski M., Dudaczyk M., 2010, Geografia dla gimnazjum, podręcznik, Operon, Gdynia.

Czepczyński M., 2006, Przemiany form i znaczeń krajobrazów kulturowych miast po socjalizmie, [w:] W. Wołoszyn (red.), Krajobraz kulturowy. Cechy, walory, ochrona, Problemy Ekologii Krajobrazu, 18, Zakład Ochrony Środowiska UMCS, Lublin, s. 59-66.

Czepczyński M., 2008, Cultural Landscape of Post-socialist Cities. Representation of Powers and Needs, Ashgate, Adlershot.

Czepczyński M., 2010, Gdańskie krajobrazy pamięci i zapomnienia: (re)interpretacje przestrzeni miejskiej ostatnich 20 lat, Kultura i Edukacja, 3 (77), s. 142-155.

Dzieciuchowicz J., Klima E., Mordwa S., Retkiewicz W., 2004, Rola wyznań religijnych w ksztattowaniu przestrzeni miejskiej Łodzi, Wydawnictwo Uniwersytetu Łódzkiego, Łódź.

Eberhardt P., 1994a, Przemiany narodowościowe na Białorusi, Editions Spotkania, Warszawa.

Eberhardt P., 1994b, Przemiany narodowościowe na Ukrainie XX wieku, Biblioteka Obozu, Warszawa.

Eberhardt P., 1996, Między Rosja a Niemcami, Wydawnictwo Naukowe PWN, Warszawa.

Eberhardt P., 1997a, Problematyka demograficzna pogranicza polsko-litewskiego, Przegląd Geograficzny, 69, 1-2, s. 28-51.

Eberhardt P., 1997b, Przemiany narodowościowe na Litwie, Przegląd Wschodni, Warszawa. 
Eberhardt P., 1998, Polska ludność kresowa. Rodowód, liczebność, rozmieszczenie, Wydawnictwo Naukowe PWN, Warszawa.

Eberhardt P., 2002, Zróżnicowania etniczno-kulturowe na obszarze postsowieckim, [w:] E. Orłowska (red.), Kultura jako przedmiot badań geograficznych. Studia teoretyczne i regionalne, 1, Oddział Wrocławski PTG, Wrocław, s. 185-193.

Eberhardt P., 2006, Przemiany struktury etnicznej ludności Polski w XX wieku, Sprawy Narodowościowe. Seria Nowa, 28, s. 53-74.

Eberhardt P., 2008a, Struktura narodowościowa ludności Polski, Rocznik Nauk Społecznych, 36, s. 145-170.

Eberhardt P., 2008b, Etniczne podtoże mozaiki religijnej Pótwyspu Batkańskiego, [w:] E. Orłowska, J. Klementowski (red.), Kulturowy aspekt badan geograficznych. Studia teoretyczne i regionalne, 5, Oddział Wrocławski PTG, Wrocław, s. 57-72.

Eberhardt P., 2010, Migracje polityczne na ziemiach polskich (1939-1950), Instytut Zachodni, Poznań.

Figlus T., 2009, Past and present of Hutsulshchyna as the Carpathian borderland region. Remarks on changes of spatial structures, ethno-cultural specificity and heritage, Region and Regionalism, 9, 2, s. 143-159.

Figlus T., 2015, The cultural heritage of rural settlement in Polish Orava, Region and Regionalism, 12, 1, s. 207-218.

Gawryszewski A., 2005, Ludność Polski w XX wieku, Monografie IGiPZ PAN, 5, Warszawa.

Grabowska-Lusińska I., Okólski M., 2008, Emigracja z Polski po 1 maja 2004 r., jej intensywność $i$ kierunki geograficzne oraz alokacja migrantów na rynkach pracy krajów Unii Europejskiej, CMR Working Papers, 33.

Heffner K., 1998, Ethnically mixed regions in the Polish conceptions of regionalisation: the Opole Region in Silesia, [w:] J. Burdack, F.-D. Grimm, L. Paul (red.), The Political Geography of Current East-West Relations, Institut für Länderkunde, Lipsk, s. $214-230$.

Heffner K., Solga B., 2003, The German minority of Opole Silesia as a minority of social and cultural borderland, Region and Regionalism, 6, 1, s. 73-81.

Jackowski A., 1991, Zarys geografii pielgrzymek, Wydawnictwo Uniwersytetu Jagiellońskiego, Kraków.

Jackowski A., 2003, Święta przestrzeń świata. Podstawy geografii religii, Wydawnictwo Uniwersytetu Jagiellońskiego, Kraków.

Jackowski A., 2007, Rozważania o krajobrazie sakralnym, [w:] K. Ostaszewska, I. Szumacher, S. Kulczyk, E. Malinowska (red.), Znaczenie badań krajobrazowych dla zrównoważonego rozwoju. Profesorowi A. Richlingowi w 70. rocznice urodzin i 45-lecie pracy naukowej, Wydawnictwo Uniwersytetu Warszawskiego, Warszawa, s. 133-144.

Jackowski A., Witkowska A., Jabłoński Z., Sołjan I., Bilska E., 1995, Przestrzeń i sacrum. Geografia kultury religijnej w Polsce i jej przemiany w okresie od XVII do XX w. na przykładzie ośrodków kultu i migracji pielgrzymkowych, Instytut Geografii UJ, Kraków.

Janicki W., 2009, Minority recognition in nation-states - the case of Silesians in Poland, [w:] T. Drobik, M. Sumberova (red.), Modern Human Geographical Thought, Cambridge Scholar Publishing, Cambridge, s. 155-184.

Klima E., 2011, Przestrzeń religijna miasta, Wydawnictwo Uniwersytetu Łódzkiego, Łódź.

Kop J., Kucharska M., Szkurłat E., 2013, Geografia dla maturzysty. Geografia społeczno-ekonomiczna świata, podręcznik, zakres rozszerzony, PWN, Warszawa.

Koter M., 1993, Geographical classifications of ethnic minorities, [w:] A. Gosar (red.), Geography and Ethnicity, Geographica Slovenica, 24, Ljubljana, s. 123-138. 
Koter M., 1995, Ludność pogranicza - próba klasyfikacji genetycznej, Acta Universitatis Lodziensis, Folia Geographica, 20, s. 239-246.

Koter M., 1997, Kresy państwowe - geneza i właściwości w świetle doświadczeń geografii politycznej, [w:] K. Handke (red.), Kresy - pojęcie i rzeczywistość, Slawistyczny Ośrodek Wydawniczy, Warszawa, s. 9-52.

Koter M., 2003, Multicultural border regions of Europe - forms of ethnic composition and process of their differentiation, Region and Regionalism, 6, 1, s. 13-22.

Koter M., Kulesza M., Puś M., Pytlas S. (red.), 2005, Wpływ wielonarodowego dziedzictwa kulturowego Łodzi na wspótczesne oblicze miasta, Wydawnictwo Uniwersytetu Łódzkiego, Łódź.

Koter M., Liszewski S., Suliborski A., 2000, Łódź i region Polski Środkowej, podręcznik wiedzy o regionie dla liceów, Łódzkie Towarzystwo Naukowe, Łódź.

Koter M., Liszewski S., Suliborski A., Wieczorek T., 2002, Łódź i województwo, podręcznik wiedzy o regionie dla gimnazjum, Łódzkie Towarzystwo Naukowe, Łódź.

Kowalski M., 1998, Problematyka etniczna wschodniego pogranicza Polski, [w:] J. Kitowski (red.), Czynniki i bariery regionalnej wspótpracy transgranicznej, Wydział Ekonomiczny Filii UMCS w Rzeszowie, Rzeszów, s. 285-294.

Kowalski M., 1999, Kulturowe uwarunkowania stosunków polsko-litewsko-biatoruskich, [w:] J. Kitowski (red.), Problematyka geopolityczna Europy Środkowej i Wschodniej, Wydział Ekonomiczny Filii UMCS w Rzeszowie, Rzeszów, s. 77-88.

Kowalski M., 2002, Mniejszość polska na Grodzieńszczyźnie, mniejszość białoruska na Biatostocczyźnie, [w:] Sadowska-Snarska C. (red.), Problemy rozwoju przygranicznych regionów wschodniej Polski, Wyższa Szkoła Ekonomiczna w Białymstoku, Białystok, s. $89-106$.

Kowalski M., 2010, Wileńszczyzna - region pogranicza polsko-litewsko-białoruskiego, [w:] A. Szerląg (red.), Wileńszczyzna mała ojczyzna, Oficyna Wydawnicza „Atut”, Wrocław, s. 65-89.

Kowalski M., 2013a, Księstwa Rzeczpospolitej. Państwo magnackie jako region polityczny, Prace Geograficzne, IGiPZ PAN, 238, Warszawa.

Kowalski M., 2013b, Ludność polska w wieloetnicznych regionach Litwy, Łotwy i Białorusi, Studia z Geografii Politycznej i Historycznej, 2, s. 205-238.

Kozłowski L., 2011, The persistence and interaction of multi-ethnic settlement remnants in the cultural landscape, Bulletin of Geography, Socio-economic Series, 16, s. 35-55.

Kubal A., 2012, Cultural Diversity and Law: Socio-Legal Integration: Polish Post-2004 EU Enlargement Migrants in the United Kingdom, Ashgate Publishing Group (e-book).

Kulesza M., 2013, Wielokulturowe dziedzictwo Łodzi a wspótczesny krajobraz miasta, Studia z Geografii Politycznej i Historycznej, 2, s. 11-46.

Kulesza M., 2014, Multinational cultural heritage in the landscape of contemporary Poland, [w:] T. Marszał (red.), Society and Space in Contemporary Poland, Łódź University Press, Łódź, s. 113-136.

Kulesza M., Łapa M., Walicki J. (red.), 2010, Rola wspólnot wyznaniowych w historii miasta Łodzi, Centrum Badań Żydowskich UŁ, Łódź.

Kulesza M., Rykała A., 2006, Przeszłość i teraźniejszość - wptyw wielonarodowego dziedzictwa kulturowego na wspótczesny krajobraz miast Polski Środkowej, Acta Facultatis Studiorum Humanitatis et Naturae Universitatis Prešoviensis. Folia Geographica, 10, s. 300-308.

Kurek S., 2012, Geografia, podręcznik dla szkół ponadgimnazjalnych, zakres podstawowy, Operon, Gdynia. 
Kuźnieców J., 2003, W mojej małej ojczyźnie: Małopolska: edukacja regionalna - dziedzictwo kulturowe w regionie, Demart, Warszawa.

Lenartowicz B., Wójcik M., 2014, Czas na geografię, podręcznik do szkół ponadgimnazjalnych, zakres podstawowy, PWN, Warszawa.

Leśniewska K., 2014, Geograficzno-polityczne uwarunkowania sytuacji mniejszości polskiej na Litwie $i$ Łotwie po 1990 roku, Wydział Nauk Geograficznych, Uniwersytet Łódzki, maszynopis.

Leśniewska K., Barwiński M, 2015, Polish heritage in the multicultural borderland - the case of Vilnius Region, Region and Regionalism, 12, 1, s. 179-191.

Liszewski S., 1991, Rola społeczności żydowskiej w organizacji przestrzeni miejskiej Łodzi [w:] S. Liszewski, W. Puś (red.), Dzieje Żydów w Łodzi 1820-1944. Wybrane problemy, Wydawnictwo Uniwersytetu Łódzkiego, Łódź.

Łęcka I., Mularczyk M., 2012, Po prostu geografia, podręcznik do szkół ponadgimnazjalnych, zakres podstawowy, WSiP, Warszawa.

Majchrzak T., 2009, Geografia 2. Nowa nasza planeta, podręcznik dla gimnazjum, PWN, Warszawa-Łódź.

Majchrzak T., Wład P., 2010, Geografia 3. Nowa nasza planeta, podręcznik dla gimnazjum, PWN, Warszawa-€ódź.

Matykowski R., Dominik A., 2010, Polska emigracja zarobkowa w Irlandii w latach 20042007, Przegląd Geograficzny, 82, 2, s. 257-280.

Myga-Piątek U. (red.), 2001, Krajobraz kulturowy. Idee, problemy, wyzwania, Prace Komisji Krajobrazu Kulturowego PTG, 1.

Myga-Piątek U. (red.), 2004, Przemiany krajobrazu kulturowego Karpat. Wybrane aspekty, Prace Komisji Krajobrazu Kulturowego PTG, 3.

Myga-Piątek U. (red.), 2005, Krajobraz kulturowy. Aspekty teoretyczne i metodologiczne, Prace Komisji Krajobrazu Kulturowego PTG, 4.

Nowak M. (red.), 2003, Edukacja regionalna w gimnazjum. Lubelszczyzna, Wydawnictwo Uniwersytetu Marii Curie-Skłodowskiej, Lublin.

Okła G. (red.), 2002, Mała Ojczyzna Świętokrzyskie. Dziedzictwo kulturowe, Zakład Wydawniczy SFS, Kielce.

Orłowska E. (red.), 2002, Kultura jako przedmiot badan geograficznych. Studia teoretyczne i regionalne, t. 1, 2, Oddział Wrocławski PTG, Wrocław.

Orłowska E. (red.), 2004, Kulturowy aspekt badań geograficznych. Studia teoretyczne i regionalne, t. 4, Oddział Wrocławski PTG, Wrocław.

Osuch W. (red.), 2007, Wybrane problemy edukacyjne i kulturowe niektórych mniejszości narodowych i etnicznych w Polsce $i$ Europie, Geoinfo, Kraków.

Piróg D., 2007, Edukacja międzykulturowa w polskiej szkole - stan, potrzeby oraz wyzwania (rozważania teoretyczne i wyniki badań), [w:] W. Osuch (red.), Wybrane problemy edukacyjne $i$ kulturowe niektórych mniejszości narodowych $i$ etnicznych w Polsce $i$ Europie, Geoinfo, Kraków, s. 32-40.

Piróg D., 2008a, Rola edukacji międzykulturowej w przygotowaniu dzieci i młodzieży polskiej do funkcjonowania w przestrzeni Unii Europejskiej, [w:] A. Zduniak, T. Smal (red.), Edukacja XXI wieku. Edukacja bez granic - mimo barier, Wydawnictwo WSB, Poznań, s. 62-73.

Piróg D., 2008b, Uwarunkowania poziomu otwartości kulturowej polskiej młodzieży akademickiej wobec wybranych narodów Europy, [w:] E. Orłowska (red.), Kultura jako przedmiot badan geograficznych. Studia teoretyczne i regionalne, 1, Oddział Wrocławski PTG, Wrocław, s. 29-44.

Plit F., 2005, Krajobrazy i regiony (w tym kulturowe), Geografia w Szkole, 2, s. 82-87. 
Plit F., 2008, Województwo podlaskie - region pogranicza, [w:] D. Świątek, M. Bednarek, P. Siłka (red.), Wspótczesne problemy badan geografii polski - geografia człowieka, Dokumentacja Geograficzna, 36, IGiPZ PAN, s. 7-14.

Plit F., 2010, Krajobrazy kulturowe w geografii fizycznej i w geografii człowieka, [w:] M. Barwiński (red.), Obszary metropolitalne we wspótczesnym środowisku geograficznym, t. 2, Oddział Łódzki PTG, WNG UŁ, Łódź, s. 99-106.

Plit F., 2011, Krajobraz kulturowy - czym jest?, Wydawnictwo Uniwersytetu Warszawskiego, Warszawa.

Plit F., 2013, Elementy sakralne w krajobrazie pogranicza czy w krajobrazie granicy?, Prace Komisji Krajobrazu Kulturowego PTG, 19, s. 62-72.

Plit F., 2014, Podlasie - the landscape of cultural borderland, and not of the boundary, Prace Komisji Krajobrazu Kulturowego PTG, 23, s. 165-176.

Plit J., 2011, Piętno wtadzy i wtaścicieli odciśnięte w krajobrazie kulturowym, Prace Komisji Krajobrazu Kulturowego PTG, 15, s. 125-141.

Plit J., 2015, Regionalizacja wspótczesnych krajobrazów historyczno-kulturowych Polski, Prace Komisji Krajobrazu Kulturowego PTG, 27, s. 79-94.

Plit J. (red.), 2006, Granice i ich rola w krajobrazie, Prace Komisji Krajobrazu Kulturowego PTG, 56.

Plit F., Osuch W., Sielatycki M., Wrona J., 2003, Geografia część 2. Człowiek i jego działalność, podręcznik dla liceum ogólnokształcącego, zakres rozszerzony, WSiP, Warszawa.

Rachwał T., 2013, Oblicza geografii 2, podręcznik dla liceum ogólnokształcącego i technikum, zakres rozszerzony, Nowa Era, Warszawa.

Rembowska K., 2002, Kultura w tradycji i we wspótczesnych nurtach badań geograficznych, Wydawnictwo Uniwersytetu Łódzkiego, Łódź.

Rembowska K., 2007, Kulturowy zwrot w geografii, [w:] W. Maik, K. Rembowska, A. Suliborski (red.), Podstawowe idee i koncepcje w geografii, 3, Wydawnictwo Uczelniane WSG, Bydgoszcz, s. 189-202.

Rykała A., 2003, Dziedzictwo materialne Żydów w krajobrazie kulturowym województwa tódzkiego, [w:] E. Orłowska, J. Klementowski (red.), Kulturowy aspekt badań geograficznych. Studia teoretyczne i regionalne, Oddział Wrocławski PTG, Wrocław, s. $85-100$.

Rykała A., 2007, Przemiany sytuacji społeczno-politycznej mniejszości żydowskiej w Polsce po drugiej wojnie światowej, Wydawnictwo Uniwersytetu Łódzkiego, Łódź.

Rykała A., 2009, Z ziemi ukraińskiej do polskiej-dziedzictwo religijne Kresów Rzeczypospolitej w przestrzeni wspótczesnej Polski, [w:] M. Franz (red.), Od Zborowa do NATO (1649-2009). Studia z dziejów polsko-ukrainskich, Wydawnictwo Adam Marszałek, Toruń, s. 106-148.

Rykała A., 2011, Mniejszości religijne w Polsce - geneza, struktury przestrzenne, tło etniczne, Wydawnictwo Uniwersytetu Łódzkiego, Łódź.

Rykała A. (red.), 2013, Przestrzenny wymiar wielokulturowego dziedzictwa, Studia z Geografii Politycznej i Historycznej, 2, Łódź.

Sadowski A., 1995, Pogranicze polsko-biatoruskie. Tożsamość mieszkańców, Trans Humana, Białystok.

Sobczyński M., 2000, Struktura narodowościowo-wyznaniowa Polski, Acta Universitatis Lodziensis, Folia Geographica Socio-Oeconomica, 3, s. 157-174.

Sobczyński M., 2012, Interakcja „badacz - podmiot badania” w studiach nad mniejszościami narodowymi w Polsce, Studia z Geografii Politycznej i Historycznej, 1, s. 95-112. 
Sobczyński M., Grabowska E., 1993, Metodologiczne problemy badania mniejszości narodowych i religijnych, [w:] Geopolitical and Social Problems of the Former Socialistic Countries. Conference Papers, Soczewka.

Soja M., 2001, The cultural and ethnic diversity of the population of Łemkowszczyzna (Lemko Region) in the 19th and 20th century, Region and Regionalism, 5, s. 212-221.

Sołjan I., 2012, Sanktuaria i ich rola w organizacji przestrzeni miast na przyktadzie największych europejskich ośrodków katolickich, Instytut Geografii i Gospodarki Przestrzennej UJ, Kraków.

Szczepankiewicz-Battek J., 2001, The multicultural character of east Lusatia and its role in cross-border cooperation, Region and Regionalism, 5, s. 100-104.

Szczepankiewicz-Battek J., 2005a, Łużyce - przestrzeń dysocjacji kultur narodowych i religijnych, Pomorska Akademia Pedagogiczna, Słupsk.

Szczepankiewicz-Battek J., 2005b, Kościoty protestanckie $i$ ich rola społeczno-kulturowa, Silesia, Wrocław.

Szczypiński D., Wójtowicz M., 2010, Planeta Nowa 2, podręcznik do geografii dla klasy II gimnazjum, Nowa Era, Warszawa.

Szubert M., 2010, Planeta Nowa 3, podręcznik do geografii dla klasy III gimnazjum, Nowa Era, Warszawa.

Świętek A., Kurek S., Osuch W., Rachwał T., 2014, Jak edukować dzieci romskie? Propozycje dla nauczycieli w zakresie ksztatcenia romskiej mniejszości etnicznej, Uniwersytet Pedagogiczny w Krakowie, Kraków.

Tanaś S., 2013, Tanatoturystyka. Od przestrzeni śmierci do przestrzeni turystycznej, Wydawnictwo Uniwersytetu Łódzkiego, Łódź.

Więckowski M., Malarz R., 2014, Oblicza geografii 3, podręcznik dla liceum ogólnokształcącego i technikum, zakres rozszerzony, Nowa Era, Warszawa.

Zaniewicz Z., 2012, Geografia. Ciekawi świata, podręcznik dla szkół ponadgimnazjalnych, zakres podstawowy, Operon, Gdynia.

[Wpłynęło: luty; poprawiono: maj 2016 r.]

\section{MAREK BARWIŃSKI}

\section{MULTICULTURALISM IN CONTEMPORARY GEOGRAPHICAL STUDIES AND GEOGRAPHICAL EDUCATION IN POLAND - AN OUTLINE OF THE SUBJECT}

Poland is a peculiar example of country which had a very rich tradition of being one of Europe's most multicultural societies, and at the same time most tolerant and open to "others", notwithstanding a contemporary history characterised by a notable degree of national and religious homogeneity, as well as the aversion of a large part of society (and some political parties) to immigrants, especially those from beyond European culture. This is also visible in any attempt to outline contemporary geographical research in multiculturalism, as well as its presence in geographical education.

The following general conclusions could be formulated on the basis of the analysis carried out:

- The vast majority of research topics taken up concern relics of the former Polish multiculturalism - small and strongly integrated national, ethnic and religious minorities, 
cultural heritage attesting to the rich and proud history of Poland, and the presence of Polish culture and tradition in eastern borderland regions that lives on through centres of Polish minorities. Overall, it is what might be described as "sentimental multiculturalism" (internal, historical, traditional and indigenous);

- The same relationship can be seen in school-level geographical education, which shows Polish multiculturalism through the lens of centuries-old, but currently scarce national and religious diversity, as well as the migration of Poles to the United Kingdom. At the same time, societies with different skin colours and non-Christian religions are located in far-away, exotic countries.

- Despite the latest censuses showing a dynamic increase in numbers of the so-called regional minorities (especially Silesian and Kashubian) that dominate the contemporary ethnic structure of Poland, as well as their intensified social, cultural and political aspirations, there has been no proportionate upsurge of interest on the part of geographers;

- Geographical research marginalises the issue of "immigrant multiculturalism" (external, modern and immigrant), despite this being an important research, journalistic, economic and political issue in the European Union for decades, and especially now.

This perception of, and research on multiculturalism, in Polish geography is to a large extent understandable, in line with the historical and cultural importance of the so-called traditional minorities on the one hand, and - on the other - the lack of attractiveness of our country as a destination for settlement among economic migrants and refugees from the Middle East and North Africa.

Despite all of that, Poland will ultimately not differ from Western Europe, in that it will not avoid a further increase in multiculturalism, given that no minority will either fully emigrate or fully integrate. Sooner or later, the influx of immigrants from nonEuropean cultures will increase, and the waves of legal and illegal immigration will not omit Poland. The substantive and mental preparation of Polish society for this "immigrant multiculturalism" - in a manner that is free of both populism and political correctness - represents a huge challenge for geographers, but also for sociologists, political scientists and historians.

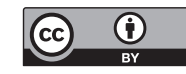


http://rcin.org.pl 